IJ§ER

ISSN: $2149-5939$
International Journal of Social Sciences and Education Research

Online, http://dergipark.gov.tr/ijsser

Volume: 3(3), 2017

\title{
Ortaokul öğrencilerinin fen bilimleri dersine yönelik tutumlarının enlemsel olarak incelenmesi ${ }^{1}$
}

The latitudinal analysis of secondary school students' attitudes to science course

\author{
Pınar Ural Keleş² Süleyman Aydın³
}

\begin{abstract}
Received Date: $01 / 01 / 2017$
Accepted Date: 13 / 03 / 2017

$\ddot{\boldsymbol{O}_{z}}$

Bu araştırmanın amacı, Ortaokul ögrrencilerinin fen bilimleri dersine yönelik tutumlarının enlemsel olarak ince-

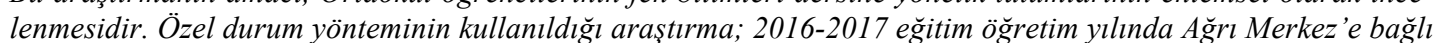
5. sinıflardan 161, altinci sinıflardan 174, yedinci siniflardan 152 ve 8. siniflardan 162 olmak üzere toplam 649 ortaokul ögrencisi ile yürütülmüşür. Araştırmada veri toplama araçları olarak; literatürden alınan ve geçerlik güvenirlik çalışması yeniden yapılarak iç tutarlılı Cronbach Alpha güvenirlik katsayısı 0,82 olarak hesaplanan "Tutum Ölçeği Testi" kullanılmıştır. Araştırmadan elde edilen verilerin analizinde SPSS 21,0 paket programı kullanılmış, gruplar arası farkın istatistiksel olarak anlamlı olup olmadı̆̆ına ise bă̆ımsız t-testi ile bakılmış ve elde edilen sonuçlar 0,05 anlamlılık düzeyinde değerlendirilmiştir. Çalışmada öğrencilerin fen tutum puan ortalamaları, 60 üzerinden en yüksek 53.99 beşinci sinıflarda en düşük ise 50.24 sekizinci sınıflarda gerçekleştiği belirlenmiştir. Araştırmada ayrıca ortaokul sinıf düzeylerinde sınıf büyüdükçe görülen fen tutum puan ortalamalarındaki düşüşünün sadece 5. sınıflar için istatistiksel olarak anlamlı olduğu diğer sinıf düzeyleri için anlamlı olmadiğg tespit edilmiştir $(p>0,05)$.
\end{abstract}

Anahtar sözcükler: Ortaokul öğrencileri, fen bilimleri dersi, fen tutum

\begin{abstract}
The aim of this research was to investigate the comparison of secondary school students' attitudes against science lessons latitudinally. In this research, the case study method was used latitudinally and it was carried out in the center schools of Agri in 2015-2016 academic year. The sample of the study was composed of totally 649 students; 161 students from 5th Class, 174 students from 6th class, 152 students from 7th class and 152 students from 8th class. An "Attitude Scale Test" taken from the literature was used as a data collection tool in the study. Cronbach Alpha reliability coefficient of the test was calculated as 0,82. SPSS 21,0 packet program was used to analyse the data and the results were assessed on 0,05 significant level of independent t-test. In the study, it was determined that the average points of students' attitudes were maximum 53,99 in 5th grades and minimum 50,24 in 8th grades over 60. In the research while secondary school class level getting grater the decrease in the science attitude scores were found to be statistically significant. $(P<0.05)$.
\end{abstract}

Keywords: Secondary school students, science course, attitude

\section{Giriş}

Eğitimde öğrenme-öğretme süreçlerinin giderek daha fazla öğrenen odaklı hale gelmesiyle, öğrenmeyi kolaylaştıran kavramlarda da ön plana çıkmıştır. Yapılan çalışmalarda öğrencilerin

\footnotetext{
${ }^{1} \mathrm{Bu}$ Çalışma 04-06 Kasım 2016 tarihinde yapılan ICSSER - $2^{\text {nd }}$ International Conference on Social Sciences and Education Research'ta Sözlü Bildiri olarak sunulmuştur.

${ }^{2}$ Yrd. Doç. Dr., Ağrı İbrahim Çeçen Üniversitesi, Eğitim Fakültesi, Matematik ve Fen Bilimleri Eğitimi Bölümü, Fen Bilgisi Anabilim Dalı, pukeles@yahoo.com

${ }^{3}$ Yrd. Doç. Dr., Ağrı İbrahim Çeçen Üniversitesi, Eğitim Fakültesi, Matematik ve Fen Bilimleri Eğitimi Bölümü, Fen Bilgisi Anabilim Dal1, yupul@hotmail.com
} 
Ural Keleş, P., Aydın, S. (2017). Ortaokul öğrencilerinin fen bilimleri dersine yönelik tutumlarının enlemsel olarak incelenmesi. International Journal of Social Sciences and Education Research, 3(2), 711-719.

başarılı olmalarında duyuşsal alan becerilerinin önemli bir etken olduğu belirtilmektedir (Duit \& Treagust, 2003; Tuan, vd., 2005; Dede \&Yaman 2008). Dolayısıyla 2013'de güncellenen Fen Bilimleri Dersi Öğretim Programı vizyonunun gerçekleştirilebilmesi “Bilgi”, "Beceri”, "Duyuş”, "Fen-Teknoloji-Toplum-Çevre (FTTÇ)" öğrenme alanlarındaki kazanımların gerçekleşmesine bağlanmıştır (MEB,2013). Fen bilimleri dersi öğretim programında duyuş öğrenme alanı "tutum", "motivasyon", "değer "ve "sorumluluk" alt öğrenme alanlarından oluşturmaktadır (MEB, 2013). $\mathrm{Bu}$ alt öğrenme alanlarından biri olan tutumun kapsamın1; "Fen bilimlerine yönelik olumlu tutum geliştirme ve fen bilimlerini öğrenmekten hoşlanma” oluşturmaktadır (MEB, 2013).

Tutum, bir derse ya da konuya karşı olumlu düşünceler besleyerek dersi sevme ya da olumlu duyuşsal özellikler gösterme halidir veya bir derse ya da konuya karşı olumsuz düşünceler besleyerek dersi sevmeme ya da olumsuz duyuşsal özellikler gösterme halidir (Kahyaoğlu \&Yangın, 2007). Bir öğrenci dersi ne kadar severse o dersi öğrenmesi ve günlük hayatta ilişkilendirmesi o kadar kolay olmaktadır (Çakır vd., 2007). Fen dersleri öğrenciler tarafından zor bir ders olarak görülmekte bu negatif tutum, istenilen başarı düzeyine ulaşılmasını engellemektedir (Yaman \& Öner, 2006). Fen tutumların olumlu ya da olumsuz olması öğrenme sürecini doğrudan etkilemekte ve bireylerin gelecekteki yaşantılarına yön vermektedir (Sünbül, vd., 2004). Fen öğretiminde öğrencilerin derse karşı tutumları, onların başarı düzeylerini oldukça fazla etkilemektedir (Bilgin \& Bahar 2002; Doğru \& Kıyıc1; 2005 Dede \&Yaman 2008). Öğrencilerin fen derslerinde başarılı olabilmeleri için, tutumlarının olumlu olması gerekmektedir (Altınok, 2005; Yeşilyurt vd., 2005; Altınok \&Açıkgöz, 2006). Yapılan araştırmalarda öğrencilerin fenne ilişkin tutumların ilkokulda daha olumlu olduğu, yaş büyüdükçe göreli olarak düştüğünü göstermektedir (George, 2000; Barmby et al. 2008; Balım, \& Aydın 2009). Bu durum, öğrencilerin büyüdükçe yeteneklerine ilişkin güvenlerini yitirmeleri ve lisede fen derslerine daha az ilgi göstermeleri ile birlikte başarılarının düşmesi şeklinde açıklanmaktadır (She, 2001).

Hiç kuşkusuz tutumların oluşmasında rol oynayan tüm etkenler arasında en çarpıcı etkiyi yapan eğitimdir (Arıkan, 2002). Öğrencilerin fene yönelik tutumların yaşantıları ile bağlantılı olduğu düşünüldüğünde öğrenme ortamlarında çok çeşitli stratejilerin yer almasının onların tutumlarını olumlu yönde etkileyeceği savunulmaktadır (Bozkurt \& Olgun, 2005; Balkan-Kıyıcı \& Atabek-Yiğit, 2010; Laçin-Şimşek, 2011). Öte yandan bir önceci öğretim programı olan fen ve teknoloji dersi öğretim programında "tutum ve değerler" öğrenme alanının zayıf kaldığı, bu alanla ilgili kazanımların, üniteler içerisine yeterince dağıtılmadığı belirtilmektedir (Çepni \& Çil 2010). Güncellenen Fen Bilimleri dersi öğretim programında ise duyuş öğrenme alanına daha fazla önem verilerek "tutum" bu öğrenme alanında yer alan dört alt öğrenme alanından biri olarak belirlenmiştir (MEB, 2013).

Dolayısıyla Fen Bilimleri dersi öğretim programına tutum alt öğrenme alanının eklenmesinin ortaokul öğrencilerin fen konularına olan tutumunu nasıl etkilediği merak konusudur. Literatürde tutumun fen öğrenimindeki etkisini ortaya koyan araştırmalar olmasına rağmen (Bilgin \& Bahar 2002; Doğru \& Kıyıc1; 2005 Dede \&Yaman 2008), güncellenen fen bilimleri öğretim programının ortaokul öğrencilerinin fen tutumuna nasıl etki ettiği ile ilgili çalışmalara rastlanmamıştır.

$\mathrm{Bu}$ araştırmanın amacı ortaokulun farklı kademelerinde öğrenim gören öğrencilerin fen bilimleri dersine yönelik tutumlarının incelenmesidir. 
Ural Keleş, P., Aydın, S. (2017). The latitudinal analysis of secondary school students' attitudes to science course. International Journal of Social Sciences and Education Research, 3(3), 711-719.

\section{Yöntem}

$\mathrm{Bu}$ araştırmada özel durum yöntemi kullanılmıştır. Problemin ayrıntılı olarak derinlemesine araştırmak için özel durum çalışmalarından faydalanmıştır (Çepni 2012). Çalışma enlemsel olarak yürütülmüşsür. Bu tür çalışmalarda örneklemin takip edeceği yaşam sürecinde ona eşdeğer olabilecek örneklem üzerinde çalışmalar yürütülerek farklı yıllardaki örneklemler üzerinde araştırma tamamlanabilir (Çepni, 2012).

\section{1. Örneklem}

Bu araştırmanın örneklemini 2016-2017 eğitim öğretim yılında Ağrı Merkez’e bağl1 5. sınıflardan 161, altınc1 siniflardan 174, yedinci sinıflardan 152 ve sekizinci sinıflardan 162 olmak üzere toplam 649 ortaokul öğrencisi oluşturmaktadır.

\subsection{Veri toplama aracı}

Bu araştırmada Nuhoğlu (2008)' e ait olan “Tutum Ölçeği Testi” kullanılmıştır. Birçok araştırmacı tarafından da kullanılan bu ölçeğin Croanbach alfa güvenirlik katsayısı 0.87 olarak belirlenmiştir (Nuhoğlu,2008). Öğrencilerin, tutum düzeylerini belirlemeyi amaçlayan ve 3'lü likert tipinde hazırlanmış ölçekte; 10'u olumlu 10' u olumsuz, toplam 20 soru yer almaktadır (Nuhoğlu, 2008). Ölçekte yer alan tutum maddeleri "okuldaki fen bilimleri dersi”, "yeni bilgiler ögrrenme ve bu bilgileri kullanma", "Fen bilimleri dersinde başarıll/başarısı olma", "Fen bilimleri dersinde etkinlik yapmayı sevme", "Fen bilimleri dersinde etkinlik yapmayl gerekli bulma" olarak adlandırılan 5 alt faktörden oluşmaktadır (Nuhoğlu, 2008).

Ölçekte öğrencilerin vermiş olduğu cevapların puanlanmasında, olumlu maddeler için 3, 2, 1 şeklinde, olumsuz maddeler için 1, 2, 3 şeklinde bir puanlama biçimi göz önüne alınmıştır. Tutum ölçeğinden alınabilecek en yüksek ve en düşük puan 60-20 arasında değişmektedir (Nuhoğlu, 2008).

Nuhoğlu (2008)' e ait olan tutum ölçeği, bu araştırmada kullanılmadan önce, 115 tane 6. sınıf öğrencisine yeniden uygulanarak ölçeğin iç tutarlılık Croanbach alfa güvenirlik katsayısı 0,82 olarak hesaplanmıştır. Kalaycı (2005)'de $.60 \leq \alpha<.80$ olan ölçeklerin "oldukça güvenilir" olduğu belirtilmektedir.

\subsection{Veri analizi}

Çalışmadan elde edilen verilerin analizinde SPSS 21.0 paket programı kullanılmıştır. Veriler Bağımsız t-Testi ile analiz edilmiş ve 0,05 anlamlılık düzeyinde değerlendirilmiştir.

\section{Bulgular}

Araştırmada öğrencilerin fen tutum puan ortalamaları ortaokulun 5 sınıfından 8. sınıfına kadar her sınıf düzeyi için ayrı ayrı hesaplanmış sınıf büyüdükçe fen motivasyon puan ortalamalarındaki değişim araştırılmıştır.

Araştırmada; ortaokulların 5. ve 6. Sınıflarında okuyan öğrencilerin fen tutum puan ortalamaları bağımsız t-testi ile karşılaştırılmış elde edilen bulgular Tablo 1 de verilmiştir. 
Ural Keleş, P., Aydın, S. (2017). Ortaokul öğrencilerinin fen bilimleri dersine yönelik tutumlarının enlemsel olarak incelenmesi. International Journal of Social Sciences and Education Research, 3(2), 711-719.

Tablo 1. Ortaokulların 5. ve 6. sınıflarında okuyan öğrencilerin fen tutum puan ortalamalarının karşılaştırılmasına ilişkin bağımsız t-testi sonuçları

\begin{tabular}{llllll}
\hline Gruplar & $\mathbf{N}$ & $\mathbf{X}$ & Ss & T & p \\
\hline 5. Sinif & 161 & 53.99 & 6,63 & 2,97 & 0,003 \\
6. Sinif & 174 & 51.71 & 7,36 & & \\
\hline${ }^{*} \mathrm{p}<0,05$ & & & & &
\end{tabular}

Tablo 1' de görüldüğü üzere öğrencilerin fen bilimleri dersine yönelik tutum puanları 60 tam puan üzerinden 5. sınıflar için 53.99 iken 6. sınıflar için 51.71 olarak belirlenmiştir. Yapılan bağımsız t-testi sonucunda öğrencilerin fen tutum puan ortalamaları arasında 5. sınıf lehine görülen 2,28 puanlık farkın istatistiksel olarak anlamlı olduğu tespit edilmiştir $(\mathrm{p}=0,003<0,05)$.

Altıncı ve 7. sınıflarda okuyan öğrencilerin fen tutum puan ortalamalarının bağımsız t-testi ile karşılaş̧ırılmasından elde edilen bulgular Tablo 2 de verilmiştir.

Tablo 2. Ortaokulların 6. ve 7. sınıflarında okuyan öğrencilerin fen tutum puan ortalamalarının karşılaştırılmasına ilişkin bağımsız t-testi sonuçları

\begin{tabular}{llllll}
\hline Gruplar & $\mathbf{N}$ & $\mathbf{X}$ & Ss & $\mathbf{T}$ & $\mathbf{p}$ \\
\hline 6. Sinif & 174 & 51,71 & 7,36 & 1,11 & 0,265 \\
7. Sinif & 152 & 50,86 & 6,39 & & \\
\hline$* \mathrm{p}>0,05$ & & & & &
\end{tabular}

Tablo 2' de görüldüğü üzere öğrencilerin fen bilimleri dersine yönelik tutum puanları 6. sınıflar için 51,71 iken 6. sınıflar için 50,86 olarak belirlenmiştir. Yapılan bağımsız t-testi sonucunda öğrencilerin fen tutum puan ortalamaları arasında 6 . sınıf lehine görülen 0,85 puanlık farkın istatistiksel olarak anlamlı olmadı $\breve{g} 1$ tespit edilmiştir $(p=0,265>0,05)$.

Yedinci ve 8. sınıflarda okuyan öğrencilerin fen tutum puan ortalamalarının bağımsız t-testi ile karşılaştırılmasından elde edilen bulgular Tablo 3' de verilmiştir.

Tablo 3. Ortaokulların 7. ve 8. sınıflarında okuyan öğrencilerin fen tutum puan ortalamalarının karşılaştırılmasına ilişkin bağımsız t-testi sonuçları

\begin{tabular}{llllll}
\hline Gruplar & $\mathbf{N}$ & $\mathbf{X}$ & Ss & $\mathbf{T}$ & $\mathbf{p}$ \\
\hline 7. Sinıf & 152 & 50,86 & 6,39 & 0,86 & 0,390 \\
8. Sinif & 162 & 50,24 & 6,39 & & \\
\hline${ }^{*} \mathrm{p}>0,05$ & & & &
\end{tabular}

Tablo 3' de görüldüğü üzere öğrencilerin fen bilimleri dersine yönelik tutum puanları 7. sınıflar için 50,86 iken 8. sınıflar için 50,24 olarak belirlenmiştir. Yapılan bağımsız t-testi sonucunda öğrencilerin fen tutum puan ortalamaları arasında 7. sınıf lehine görülen 0,62 puanlık farkın istatistiksel olarak anlamlı olmadığ tespit edilmiştir ( $(\mathrm{m}=0,390>0,05)$.

\section{Sonuç ve tartışma}

Ortaokulun farklı kademelerinde öğrenim gören öğrencilerinin fene yönelik tutumlarının incelenmesi amacıyla yapılan bu araştırmada, öğrencilerin motivasyon ölçeğinden max 60 puan üzerinden aldıkları ortalama puanlar; beşinci sınıflar için 53.99, altıncı sınıflar için 51.71, yedinci sınıflar için 50,86 ve 8 . sınıflar için 50,24 olarak belirlenmiştir. Genel olarak öğrencilerinin fene yönelik ortalama tutum puan ortalamalarının yüksek olduğu, fakat sınıf büyüdükçe düştüğü görülmektedir. Sınıf bazında bakıldığında ise Tablo 1,2,3 den görüldüğ̈̈ üzere sadece 5.sınıftan 
Ural Keleş, P., Aydın, S. (2017). The latitudinal analysis of secondary school students' attitudes to science course. International Journal of Social Sciences and Education Research, 3(3), 711-719.

6.sınıfa geçerken 5. sınıf lehine görülen 2,28 puanlık farkın anlamlı olduğu diğer sınıflar için anlamlı olmadığ $1(p=0,265>0,05 ;(p=0,390>0,05)$ görülmektedir. Bu noktadan hareketle ortaokul öğrencilerinin fen tutum puan ortalamalarının sadece 5.sınıftan 6 sınıfa geçerken düştüğü, diğer sınıf kademeleri için sınıf büyüdükçe aynı kaldığı söylenebilir. Genel olarak ergenlik döneminde bütün derslere karşı tutum azalmaktadır (Eccles ve Wigfield 1992). Ayrıca öğrencilerin büyüdükçe yeteneklerine ilişkin güvenlerini yitirmeleri ve fen derslerine tutumlarının azaldığı bilinmektedir (She 2001). Öğrencilerin ortaokul öğrenimleri boyunca fen tutum puanlarında görülen önemli düşüşün bu noktalar ile açıklanabileceği düşünülmektedir. Ayrıca önemli bir noktada 8 . Sınıf öğrencilerinin ortaöğretime geçiş sınavına hazırlanmalarından kaynaklanabileceği de unutulmamalıdır. İlgili literatürde sıklıkla öğrencilerin fene ilişkin tutumların ilkokulda daha olumlu olduğu, yaş büyüdükçe göreli olarak düştüğüne değinilmektedir (George, 2000; Barmby et al. 2008; Balım, \& Aydın 2009; Sinan vd., 2014). Can \& Dikmentepe (2015) tarafından 2013-2014 öğretim yılında 177 ortaokul öğrencisi ile yapılan çalışmada ortaokul öğrencilerin fen tutum puan ortalamalarının sınıf düzeyleri arasında anlamlı bir farklılık gösterdiği bu farkın 5. sınıflar lehine olduğu bildirilmektedir. Sinan vd., (2014) 296 ortaokul öğrencisi ile yaptıkları çalışmada da öğrencilerin fen ve teknoloji dersi tutumları açısından 5.ve 7., 5. ve 8., 6. ve 7., 6. ve 8. sinıflar arasında alt sınıfların lehine anlamlı farklar olduğu bildirmişlerdir. İlgili literatüre bakıldığında öğrencilerin fen tutum puanlarının ortaokulun küçük sınıflar lehine olduğu çalışmalar olduğu gibi tutum puan ortalamasının büyük sınıflar lehine anlamlı olduğu çalışmalara da rastlanmaktadır. Kaya \& Böyük (2011) 6-7-8 sınıflar ile yaptıkları çalışmada, öğrencilerin fen ve teknoloji derslerine yönelik tutum puanlarında sınıf düzeyine bağlı olarak 8. sınıfta okuyan öğrencilerin lehine anlamlı farklılık olduğunu diğer sınıf düzeylerinde ise bir farklılık olmadığını bildirmişlerdir.

Konu ile ilgili ulaşılabilen yerli literatüre bakıldığında çalışmaların fen ve teknoloji dersi öğretim programı kapsamında yürütüldüğü dikkat çekmektedir. Bu çalışma 2016-2017 öğretim y1lında fen bilimleri dersi kapsamında yürütülmüştür. Çalışmada en yüksek puan 60 puan üzerinden ortaokulun tüm sınıf düzeylerinde öğrencilerin fen tutum puan ortalamalarının yüksek olduğu ve sadece 5.sınıftan 6 sınıfa geçerken düştüğü diğer sınıf düzeylerinde ise aynı kaldığı belirlenmiştir. $\mathrm{Bu}$ çalışmalardan elde edilen sonuçların daha güçlü desteklere muhtaç olmasına rağmen güncellenen fen bilimleri programında tutum boyutun kazanımlara fen ve teknoloji öğretim programından daha etkili biçimde yerleştirilmesinden kaynaklanabileceği düşünülmektedir.

\section{1. Öneriler}

Özellikle Fen Bilimleri dersi öğretmenlerine yönelik hizmet içi kurslarının fen bilimleri dersi öğretim programının duyuş boyutunu da kapsayacak şekilde düzenlenmesi programın bu boyutunun da öğretmenler tarafından yeterince tanınmasına ve eksikliklerinin giderilmesine önemli katk1lar sağlayabilir.

\section{Kaynakça}

Altınok, H. (2005). Cinsiyet ve Başarı Durumlarına Göre İlköğretim 5. Sınıf Öğrencilerinin Fen Bilgisi Dersine Yönelik Tutumları. Eurasian Journal of Educational Research, 17, 81-91.

Altınok, H. ve Açıkgöz K. Ü. (2006). İşbirlikli ve bireysel kavram haritalamanın Fen Bilgisi dersine yönelik tutum üzerindeki etkileri. Hacettepe Üniversitesi Eğitim Fakültesi Dergisi, 30, 21-30. 
Ural Keleş, P., Aydın, S. (2017). Ortaokul öğrencilerinin fen bilimleri dersine yönelik tutumlarının enlemsel olarak incelenmesi. International Journal of Social Sciences and Education Research, 3(2), 711-719.

Arıkan Y. D. (2002). Sınıf öğretmeni adaylarının bilgisayara yönelik tutumlarl, bilgisayar kaygı düzeyleri ve bilgisayar dersine ilişkin değerlendirmeleri. Yayınlanmamış yüksek lisans tezi, Dokuz Eylül Üniversitesi, İzmir.

Balım, A. G., \& Aydın, H. S. G. (2009). Fen ve teknolojiye yönelik tutum ölçeğinin geliştirilmesi. Pamukkale Üniversitesi Eğitim Fakültesi Dergisi, 25(25), 33-41.

Balkan-Kıyıcı, F. ve Atabek-Yiğit, E. (2010). "Science education beyond the classroom: A field trip to wind power plant", International Online Journal of Educational Sciences, 2(1), 225-243.

Barmby, P., Kind. P. M., Jones, K. ve Bush, N. (2005). Evaluation of lab in a lorry, Final Report Durham University. CEM Centre of School and Education.

Bozkurt, O. \& Olgun, Ö. S. (2005). Fen ve Teknoloji Eğitiminde Bilimsel Süreç Becerileri. M, Aydoğdu ve T. Kesercioğlu (Eds), Illköğretimde Fen ve Teknoloji Öğretimi, Ankara: Anı Yayıncılık.

Bilgin, İ., \& Bahar, M. (2002). Öğretmen Adaylarının Öğrenme Stilleri ve Fen Bilgisi Dersine Karşı Tutumları Arasındaki İlişki. Abant İzzet Baysal Üniversitesi Eğitim Fakültesi Dergisi, 2(4), 53-67.

Can, Ş.\& Dikmentepe, E. (2015). Ortaokul Öğrencilerinin Fen Ve Teknoloji Dersi İle Fen Deneylerine Yönelik Tutumlarının Araştırılması (Muğla İli Örneği). Muğla Sıtkı Koçman Üniversitesi Ĕgitim Fakültesi Dergisi, 1(2), 44-58.

Çakır, N., Şenler, B. \& Taşkın, B. (2007). İlköğretim ikinci kademe öğrencilerinin fen bilgisi dersine yönelik tutumlarının belirlenmesi, Türk Ĕ̈itim Bilimleri Dergisi, 5(4), 637- 655.

Çepni, S., (2012). Araştırma ve Proje Çalışmalarına Giriş. Geliştirilmiş 6. Baskı. s 76. Ankara

Çepni, S. ve Çil, E. (2010). Fen ve Teknoloji Programı İlköğretim 1. ve 2. Kademe Öğretmen El Kitabı, Ankara: Pegem Akademi.

Doğru, M. \& Kıyıcı, F. K. (2005). Fen Ĕ̆itiminin Zorunluluğu, M. Aydoğdu ve T. Kesercioğlu (eds), İlköğretim Fen ve Teknoloji Öğretimi, Ankara: Anı Yayıncılık.

Duit, R. \& Treagust, D. (2003). Conceptual change: A powerful framework for improving science teaching and learning. International Journal of Science Education, 25(6), 671-688.

Dede, Y. \& Yaman, S. (2008). Fen Öğrenmeye Yönelik Motivasyon Ölçeği: Geçerlik ve Güvenirlik Çalışması. Necatibey Eğitim Fakültesi Elektronik Fen ve Matematik Eğitimi Dergisi (EFMED) 2(1), 19-37.

Eccles, J. S. \& Wigfield, A. (1992). The development of achievement-task values: a theoretical analysis. Developmental Review, 12, 265-310

George, R (2000). Measuring change in students' attitudes toward science over time:An aplication of talent variable Growth modelling. Journal of Science Education and Technology, 9, 213-225.

Kahyaoğlu, M. \& Yangın, S. (2007). İlköğretim öğretmen adaylarının mesleki öz-yeterliliklerine ilişkin görüşleri. Kastamonu Eğitim Dergisi, 15(1), 73-84.

Kalaycı, Ş. (2005). SPSS Uygulamalı Çok Değişkenli İstatistik Teknikleri, Asil Yayın Dağıtım, Ankara.

Kaya H .\& Böyük U. (2011). İlköğretim II. Kademe Öğrencilerinin Fen Ve Teknoloji Dersine Ve Fen Deneylerine Karşı Tutumları TÜBAV Bilim 4(2), 120-130

Laçin-Şimşek, C. (2011). “Okul Dışı Öğrenme Ortamları ve Fen Eğitimi”, Fen Öğretiminde Okul Dışı Öğrenme Ortamları. Ed.: Canan Laçin Şimşek, Ankara: Pegem Yayıncılık, s.5-24.

MEB. (2013). İlköğretim kurumları ilkokullar ve ortaokullar fen bilimleri dersi (3, 4, 5, 6, 7 ve 8. sinıflar) ögretim programı, Milli Eğitim Bakanlığı Ankara. 
Ural Keleş, P., Aydın, S. (2017). The latitudinal analysis of secondary school students' attitudes to science course. International Journal of Social Sciences and Education Research, 3(3), 711-719.

Nuhoğlu, H. (2008). İlköğretim Fen Ve Teknoloji Dersinde Sistem Dinamiği Yaklaşımının Tutuma, Başarıya Ve Farklı Becerilere Etkisinin Araştırılması, (Yayımlanmamış Doktora Tezi), Gazi Üniversitesi, Eğitim Bilimleri Enstitüsü, Ankara.

Sinan, O., Şardağ, M., Salifoğlu, A., Çakır, C. \& Karabacak, Ü. 2014 İlköğretim Öğrencilerinin Fen Tutumları ve Özyeterliliklerinin İncelenmesi NEF-EFMED Cilt 8, Say1 1, Haziran

Sünbül, M., Afyon, A., Yağız, D. \& Aslan, O., (2004). İlköğretim 2. Kademe Fen Bilgisi Derslerinde Akademik Başarıyı Yordamada Öğrencilerin Öğrenme Strateji, Stil ve Tutumlarının Etkisi , XII. Ulusal Ĕgitim Bilimleri Kongresi Bildirileri, Ankara: 1573-1588,

She, H. C. (2001). "Different Gender Students' Participation in The High and Low Achieving Middle School Questioning-Orientated Biology Classroom in Taiwan”, Research in Science \& Technological Education, 19 (2), 148-158.

Tuan, H. L, Chin, C. C., \& Shieh, S. H. (2005). The development of a questionnaire to measure students' motivation towards science learning. International Journal of Science Education, 27(6), 639-654.

Yeşilyurt, M., Kurt, T. ve Temur, A. (2005). İlköğretim fen laboratuarı için tutum anketi geliştirilmesi ve uygulanması. Pamukkale Üniversitesi Eğitim Fakültesi Dergisi, 17: 23-37.

Yaman, S. \& Öner, F. (2006). İlköğretim öğrencilerinin fen bilgisi dersine bakış açılarını belirlemeye yönelik bir araştırma. Kastamonu Ĕ̆itim Dergisi, 14(1), 339-346. 
Ural Keleş, P., Aydın, S. (2017). Ortaokul öğrencilerinin fen bilimleri dersine yönelik tutumlarının enlemsel olarak incelenmesi. International Journal of Social Sciences and Education Research, 3(2), 711-719.

\section{Extended abstract in English}

With the learning-teaching processes becoming more learner-centered in education, the concepts that facilitate learning have come to the forefront. It was reported in previous studies that affective field skills are important factors in the success of students. For this reason, the realization of the vision of the Science Class Teaching Program that was updated in 2013 was associated with the realization of the acquisitions in "Knowledge", "Skill", "Perception", "Science-Technology-Society-Environment (STSE)" fields. The perception learning field in science teaching program consist of "attitude", "motivation", "value" and "responsibility" sub-learning fields. The scope of the "attitude", which is one of the sub-learning fields, consists of "Developing positive attitude towards science and enjoying learning science". The attitudes of students towards science classes affect their success levels. On the other hand, in the Science and Technology Teaching Program", which is the previous teaching program, it is known that the "attitudes and values" learning field was weak, and the acquisitions on this field were not distributed adequately in the units. In the updated Science Classes Teaching Program, on the other hand, perceptive learning field was cared more and "attitude" was determined as one of the four sub-learning fields. For this reason, it is wondered how this situation affects the attitudes of secondary school students towards science topics. There are studies investigated on the effects of attitudes on science teaching in the literature. The effects of the updates in science teaching program on the attitudes of students towards science classes constitute the focal point of this study. The purpose of this study is to examine the attitudes of secondary school students in a latitudinal manner. The specific situation method was used in the study, and was conducted in a latitudinal manner. In such studies, analyses are made on the sampling that may be equal to the study population in the lifespan, and the study may be completed on samplings in different years. The study was conducted with 649 students 161 of which were $5^{\text {th }}$ grades, 174 of whom were $6^{\text {th }}$ grades, 152 of whom were from $7^{\text {th }}$ grade, and 162 of whom were from $8^{\text {th }}$ grade studying at a secondary school in Ağr in 2016-2017 academic year. The "Attitude Scale Test", which was used as the data collection tool in the study, was taken from the literature, and was applied to $1156^{\text {th }}$ grade students before it was used in his study, and thus, the validity and reliability of the scale was made again. The Internal Cronbach Alpha Coefficient of the scale was calculated as 0,82 . The scale was prepared in the 3-Point Likert Scale, and aimed to determine the attitude levels of the students. There were 10 positive and 10 negative questions, 20 questions in total. The items on the attitudes in the scale consisted of 5 sub-factors in the following form; "Science classes at school", "learning new things and using them", "being successful/unsuccessful at science classes", "Loving activities at science classes", "finding that activities at science classes are necessary". The highest point and the lowest point that may be received from the scale vary between 60-20. The SPSS 21,0 Package Program was used in the analysis of the data obtained in the study. And the independent $t$-test was used to determine whether the difference between the groups was significant or not; and the results obtained were evaluated at 0,05 significance level.

It was determined that the average attitude points of the students towards science classes are generally high; however, it was also determined that as the grades increased, these values decreased. The science attitude point average values of the students were determined as 53.99 for fifth grades; 51,71 for sixth grades; 50,86 for seventh grades; and as 50,24 for eighth grades. When the values are considered in terms of grades, it was determined that only the difference of 2,28 points that was detected in favor of the $5^{\text {th }}$ grades in the transition from $5^{\text {th }}$ grade to $6^{\text {th }}$ grade was significant $(p<0,05)$; and he differences for other grades were not significant $(p>0,05)$. Based 
Ural Keleş, P., Aydın, S. (2017). The latitudinal analysis of secondary school students' attitudes to science course. International Journal of Social Sciences and Education Research, 3(3), 711-719.

on this point, it may be claimed that the science attitude point averages of secondary school students decrease only when they are in the transition process from $5^{\text {th }}$ grade to $6^{\text {th }}$ grade, and at other grades, these values remain stable as the grades increase.

Generally, the interest of students decrease in all subjects when they are in the puberty period. In the relevant literature, it is frequently reported that the attitudes of students are more positive when they are at primary school level, and the level of their interest decrease at a relative level as they grow up. Although the results obtained from these studies need strong confirmation, the attitude dimension in the updated science program is placed in acquisitions in a more efficient manner than science and technology education program.

In-service training sources that will be provided for science teachers should be organized in a manner that will cover the perception dimension of the curriculum of the subject, which may ensure that teachers recognize this dimension more, and missing points are eliminated. 